\title{
Metode Relaksasi untuk Mengurangi Tingkat Stress pada Ibu dalam Mendampingi Anak di Era Pandemi
}

\author{
Eva Gustiana $^{1 凶}{ }^{\bowtie}$ Chitra Charisma Islami ${ }^{1}$ \\ Pendidikan Guru Pendidikan Anak Usia Dini, Sekolah Tinggi Keguruan dan Ilmu \\ Pendidikan Muhammadiyah Kuningan(1) \\ DOI: 10.31004/obsesi.v6i3.1810
}

\begin{abstract}
Abstrak
Perubahan situasi dan kondisi covid saat ini yang mempengaruhi kondisi orang tua sehingga tidak sedikit yang mengalami stress. Dengan fenomena yang ada dilapangan maka dari itu, penelitian ini bertujuan untuk mengurangi tingkat stress pada ibu dalam mendampingi anak SFH (School From Home) di Era Pandemi ini. Penelitian ini dilakukan dengan mengunakan metode quasi experimental design, yaitu suatu penelitian yang memiliki bentuk menyerupai dengan eksperimen. Menggunakan teknik total sampling dengan jumlah responden $10 \mathrm{ibu}$ dari siswa yang menemani SFH dengan mengisi isian kuesioner (Graziano \& Morgenstern, 1989). Rancangan penelitian yang digunakan adalah one group before-after, (pretest-postest design) dimana akan dilihat perbedaan hasil test peserta sebelum dan sesudah pelaksanaan variabel independent. Berdasarkan hasil analisis data menunjukkan bahwa metode relaksasi dapat menurunkan tingkat stress pada ibu ketika mendampingi anak SFH. Untuk peneliti selanjutnya bisa mengembangkan tenik relaksasi dalam menangani stress orangtua siswa bukan hanya di tingkat PAUD namun di tingkat sekolah dasar dan lanjutan.
\end{abstract}

Kata Kunci: metode relaksasi; tingkat stress; sfh.

\begin{abstract}
Changes in the situation and conditions of the current covid that affect the condition of parents so that not a few are experiencing stress. With the phenomena that exist in the field, therefore, this study aims to reduce stress levels for mothers in accompanying SFH (School From Home) children in this Pandemic Era. This research was conducted using a quasi-experimental design method, which is a study that has a shape similar to an experiment. Using a total sampling technique with the number of respondents 10 mothers of students who accompany SFH by filling out the questionnaire (Graziano, Anthony, 2000). The research design used was one group before-after, (pretest-posttest design) where the differences in the test results of participants before and after the implementation of the independent variables would be seen. Based on the results of data analysis, it shows that the relaxation method can reduce stress levels for mothers when accompanying SFH. For further researchers, they can develop relaxation techniques in dealing with parental stress, not only at the PAUD level but at the elementary and secondary school levels.
\end{abstract}

Keywords: relaxation method; stress level; sfh.

Copyright (c) 2021 Eva Gustiana, Chitra Charisma Islami

$\triangle$ Corresponding author :

Email Address : eva_psikologi@upmk.ac.id (Kuningan, Indonesia)

Received 17 September 2021, Accepted 13 December 2021, Published 30 December 2021 


\section{PENDAHULUAN}

Sejumlah provinsi mulai Senin 16 Maret 2020 meliburkan sekolah, dari jenjang TK, SD, SMP dan SMA hingga Senin 30 Maret 2020 Langkah itu diambil untuk mengantisipasi penyebaran virus corona (Covid-19) di lingkungan lembaga pendidikan (Republika.co.id). Saat ini bulan Oktober 2020 khususnya di Kabupaten Kuningan Jawa Barat masih dilakukan pembelajaran di rumah yang istilah kerennya sering disebut SFH. Penelitian yang dilakukan di Hongkong yang dikutip dari CNN Indonesia (Kamis 26 Maret 2020) (Friedenberg, 1995), bahwa penutupan sekolah untuk mencegah penyebaran infeksi virus corona berdampak pada kesehatan mental orang tua yang menurun drastis. Penelitian terbaru di Hong Kong menyurvei para orang tua mengenai work from home dan penutupan sekolah. Survei dari Lembaga Nirlaba Hong Kong, Institute of Family Education ini melibatkan lebih dari 500 orang tua. 85 persen orang tua mengaku stres dan tidak senang dengan penutupan sekolah. Orang tua yang juga harus bekerja dari rumah memiliki tingkat stres tertinggi karena penutupan sekolah. Christopher Yu Wing-fai, orang tua merasa stres karena anak kesulitan dalam belajar secara daring (online)."

Pandemi Covid-19 mengharuskan para pelajar untuk melaksanakan kegiatan pembelajaran secara jarak jauh. Orang tua pelajar pun turut merasakan dampaknya, mereka mengeluh karena tidak mampu mendukung kegiatan pembelajaran anaknya dari rumah. Berbagai kendala dihadapi oleh para orang tua, mulai dari tidak memiliki pengalaman mengajar, sistem pembelajaran daring yang kurang interaktif, hingga kurangnya motivasi belajar dari sang anak. Penelitian ini bertujuan untuk memberikan gambaran permasalahan orang tua dalam memandu anak mereka belajar pada masa SFH. Metode pada penelitian ini menggunakan paradigma berpikir positivisme dengan pendekatan kuantitatif deskriptif serta metode purposive, non-probability sampling. Kuesioner disebarkan kepada orang tua murid sekolah dasar (usia dini, kelas 1-3) yang saat ini anaknya sedang melaksanakan Pembelajaran Jarak Jauh (PJJ). 131 responden menjawab sejumlah pertanyaan seputar kesulitan yang dihadapi selama membantu anak belajar dari rumah. Hasil dari penelitian ini menunjukkan bahwa minimnya pengalaman dan ilmu dalam mengajar anak, sistem belajar yang tidak interaktif dari sekolah, dan kurangnya motivasi belajar anak selama PJJ menyebabkan para orang tua kesulitan membantu anak belajar. Hasil dari riset ini dapat digunakan oleh seluruh pihak yang peduli mengenai PJJ bagi anak usia dini untuk membuat program dan solusi praktis dalam mengatasi masalah yang ada (Covid-, 2021).

Pandemi Coronavirus Disease (Covid-19) yang telah menyebar ke berbagai negara termasuk Indonesia mengharuskan berbagai sektor untuk segera mengambil sikap dalam mencegah penularan yang lebih luas, termasuk sektor pendidikan. Berkaitan dengan hal tersebut Kementerian Pendidikan dan Kebudayaan mengambil sikap tegas melalui beberapa surat edaran berkaitan tentang kebijakan pendidikan dalam masa darurat penyebaran Covid19. Tulisan ini mengkaji pelaksanaan kebijakan pendidikan dalam masa darurat Covid-19 berkaitan dengan kebijakan pembelajaran dari rumah. Proses belajar dari rumah melalui pendidikan jarak jauh merupakan solusi yang dalam pelaksanaannya belum optimal secara keseluruhan. Terdapat berbagai hambatan, baik dari sisi sumber daya manusia, pengaturan penyelenggaraan, kurikulum, maupun sarana belajar. Komisi X DPR RI perlu mendorong sinergitas berbagai sektor terkait serta melakukan pengawasan agar pelaksanaan kebijakan belajar dari rumah dapat berjalan secara optimal (Arifa, 2020).

Di Indonesia ada kasus anak dibunuh orang tua karena tingkat stress yang tinggi, yang dikutip dari Detik. News bahwa, Suami-istri, IS (27) dan LH (26), nekat membunuh anak perempuannya yang berusia delapan tahun (Chairini, 2013). Urusan sepele berujung petaka. Kepada polisi, pelaku murka karena anaknya sulit belajar online.

Hasil penelitian dalam jurnal Psychiatry Research mensurvei lebih dari 7.200 pria dan wanita si China selama lockdown yang diberlakukan pada Februari di negara itu. Lebih dari sepertiga ditemukan menderita "gangguan kecemasan umum" terkait-COVID, sementara 
sekitar seperlima berjuang dengan adanya tanda-tanda depresi. Sedangkan lebih dari 18\% mengatakan adanya aktivitas kesulitan untuk tidur (Huang \& Zhao, 2020).

Menurut Wong (Council, 2004) yang dikutip dari Chairini Nurul, bahwa stres pada orang tua khususnya pada ibu, akan berpengaruh pada kemampuan orang tua dalam menjalankan peranan pengasuhan terutama terkait strategi Coping yang digunakan dalam mengatasi permasalahan anak. Namun kondisi anak juga dapat menyebabkan stress pada orang tua. Peningkatan stres yang berhubungan dengan anak dan pengasuhan mempunyai pengaruh negatif terhadap perkembangan anak. Sementara itu, Fildzar dalam penelitiannya yang berjudul "Kegiatan Relaksasi Sebagai Coping Stress di masa Pandemi Covid-19" memaparkan bahwa efektifitas metode relaksasi sebagai alternatif mengatasi stres selama pandemi Covid-19. Sehingga relaksasi dapat dijadikan sebagai alternatif teknik sosial yang mendukung proses adaptasi individu dan kelompok, serta komunitas.

Metode relaksasi sangat memungkinkan dilaksanakan untuk mengurangi tingkat stress pada ibu (Kirkpatrick, Donald, 2006). Agar pembelajaran daring atau bahasa kerennya SFH bisa berjalan secara efektif dengan hasil pembelajaran yang optimal. Peneliti mendapatkan keluhan dari para ibu yang mengalami stress dan menjadi agresif kepada anaknya ketika mendampingi anaknya SFH.

Untuk itu, berdasarkan hasil dari pra-penelitian yang diperoleh dan didukung oleh pendapat para ahli perlu adanya metode relaksasi untuk mengurangi tingkat stres pada ibu dalam mendampingi anak SFH di era pandemi. Tujuan penelitian ini adalah mendeskripsikan keefektifan motode relaksasi untuk mengurangi tingkat stress pada ibu yang mendampingi anaknya. Relaksasi dapat dilakukan untuk mengatasi stress, dimana akan terjadi peningkatan aliran darah sehingga perasaan cemas dan khawatir akan berkurang (Abbasi et al,. 2018).

Istilah stress mengacu pada kondisi tubuh yang menjadi tegang saat berusaha menyesuaikan diri da lam melaksanakan aktivitas sehari-hari yang sulit. Stress adalah kondisi yang tidak menyenangkan dimana manusia melihat adanya tuntutan da lam suatu kondisi sebagai bebab atau di luar kemampuan mereka untuk memenuhi tuntutan tersebut. Menurut Nasir (2011) mendefinisikan stress merupakan hubungan interaksi individu dengan lingkungan sekitar yang dapat menimbulkan suatu kondisi persepsi tuntutan yang berasal dari system biologis, psikologis dan sosialdari sesorang (Nasir, 2011). Stress bisa dapat juga diartikansebagai tekanan, ketegangan atau gangguan yang tidak menyenangkan yang berasa 1 dari luar diri seseorang dan karena itu stress dapat membuat sebuah ancaman baru yang dapat menyebabkan kecemasan, depresi disfungsi sosia 1 bahkan bisa untuk mengakhiri hidup. McPheat (2010) mendefinisikan stress adalah reaksi atau respon tubuh terhadap stresor psikososial. Faktor penyebab stress secara umum menurut Surdarya (2014) adalah a) factor internal: yaitu faktor yang timbul dari da lam diri individu itu sendiri, misalnya, kondisi fisik, perilaku, kognitif, standar yang terlalu tinggi, onflik pribadi, dan keadaan emosi. b) Faktor eksternal: yaitu faktor yang timbul dari luar diri individu, misalnya erubahan lingkuungan sekitar, keluarga uang kurang harmonis, maslah ekonomi dan sosial budaya.

Ada dua aspek utama dari dampak yang ditimbulkan akibat stress yang terjadi, yaitu aspek fisik dan aspek psikologis (Sarafino, E.P., \& Smith, 2011) yaitu: 1. Aspek Fisik Berdampak pada menurunnya kondisi seseorang pada saat stress sehingga orang tersebut mengalami sakit pada organ tubuhnya, seperti sakit kepala, gangguan pencernaan. 2. Aspek Psikologis Terdiri dari gejala kognisi, gejala emosi, dan gejala tingkah kalu. Masing-masing gejala tersebut mempengaruhi kondisi psikologis seseorang dan membuat kondisi psikologisnya menjadi negative, seperti menurunnya daya ingat, merasa sedih dan menunda pekerjaan. Hal ini dipengaruhi oleh berat atau ringannya stress.

Alat ukur untuk menentukan tingkat stress yaitu dengan menggunakan Depression Anxiety Stress Scale (DASS) (GA, 1981) yang telah teruji realiabilitas dan validitasnya dengan nilai validitas koefesien alfa depresi 0,947 , ansietas 0,897 , dan stress 0,933 . Sementara realia bilitas memiliki nilai a lfa 0,93 (Crawford \& Hanry, 2005). DASS merupakan 3 skala yang dirancang untuk mengukur keadaan emosional negatif yaitu depresi, cemas, dan stress. 
National Safety (Council, 2004) membagi stress kedalam 2 jenis stress, yaitu stress baik dan stress buruk. Suatu stress dianggap baik atau buruk tergantung pada respon seseorang terhadap stressor yang dialami. (1) Stres baik/eustress adalah sesuatu yang positif, yaitu apabila seseorang berusaha memunuhi tuntutan yang dihadapinya agar orang lain maupun dirinya sendiri mendapatkan sesuatu yang baik. Bisa dikatakan stress positif jika nila i kejadian yang dialami/dihadapi dengan berpikir positif, serta stimulus yang masuk dijadika n sebagai pembela jaran berharga dan mendorong seseorang agar berikap baik, dimana sikap tersebut dapat membawa manfaat dan memberikan motivasi. (2) Stres yang buruk/stress yang bersikap negative. Diperoleh dari proses dimana seseorang memakna i sesuatu dengan buruk, dan respon yang digunakan selalu negative dan diartikan sebagai sebuah ancaman. Stress buruk ada lah stress yang membuat individu menjadi cemas, marah, tegang, merasa bersalah dan merasa kewalahan menghadapi tekanan/stressor yang dihadapi (Nasir, 2011).

Stres akan berdampak pada suasana hati $(\operatorname{mood})$, otot kerangka (musculo sketetal), dan organ dalam tubuh (visceral). Tanda-tanda pada suasana hari (mood), adala h cemas, merasa tidak pasti, sulit tidur pada ma lam hari, suka lupa, dan gugup. Tanda -tanda musculoskeletal adalah jari-jari dan tangan gemetar, kepala mulai sakit, leher kaku atau berdiri di tempat. Tandatanda visceral adalah tangan berkeringat, ba nyak keringat, jantung berdebar, perut terganggu, mulut kering, suara bordering dalam telinga (R., 2016). Bantuan yang dapat diberikan kepada ibu yang mengalami stress dapat berupa penanganan secara medis maupun psikologis. Terapi psikologis yang sering dilakukan untuk mengurangi stress adalah dengan metode relaksasi. Beberapa penelitian membuktikan bahwa relaksasi efektif menurunkan stres.

Dalam kamus psikologi, relaksasi adalah reaksi jasmaniah da lam keadaan tenang dan emosiona 1 mediatif. Teknik relaksasi merupakan salah satu teknik pengelolaan diri yang didasarkan pada cara kerja system saraf simpatis dan para simpatis. Ketika otot-otot sudah dirilekskan maka akan menorma lkan kembali fungsi-fungsi organ tubuh. Setelah seseorang melakukan relaksasi dapat membantu tubuhnya menjadi rileks. Selain itu juga, relaksasi merupakan proses merilekskan otot-otot yang mengalami ketegangan ataumengendorkan otot-otot tubuh dan pikiran agar tercapai kondisi yang nyaman atau berada pada gelombang otak alfa-teta (Yunus, 2014). Manfaat relaksasi diantaranya adalah mengurangi tingkat stress pada seseorang yang memiliki masalah kesehatan (T.V, 2017). Manfaat yang sama juga dijelaskan oleh peneliti lain bahwasannya relaksasi dapat mengurangi tingkat streas, dimana teknik relaksasi berguna untuk meregula si emosi dan fisik individu dari kecemasan, ketegangan, stress dan lainnya, serta secara fisiologis, pelatihan relaksasi memberikan respon relaks, dimana dapat didefinisikan dengan menurunnya tekanan darah, detak jantung dan meningkatkan resisten kulit (Sari \& Subandi, 2015).

Jenis relaksasi menurut Miltenberger, (2012) dibedakan menjadi empat macam ya itu relaksasi otot (progressive muscle), relaksasi pernapasan (diapbrogmatic breathing), relaksasi dengan cara mediasi (attention focusing exercises), dan relaksasi perilaku (behavioural relaxation training) dan lain sebagainya. Relaksasi yang dilakukan da lam penelitian ini adalah relaksa si pernapasan dalam, relaksasi otot progresif dan relaksasi pernapasan dalam dapat membantu individu menurunkan stress. Pernapasan yang tepat dapat menurunkan stress dan kebiasaan bernapas yang tepat penitng untuk kesehatan fisik dan mental (Davis, M, 1995). Teknik relaksasi dalam, tujuannya menyadari serta memusatkan pikiran pada ja lannya penapasan. Pada terapi ini partisipan dilatih untuk memusatkan pikirannya pada pernapasan sehingga tidak memikirkan ha 1 negative dan dapat merasakan keluar masuknya udara melalui hidung dengan tenang. Pelaksanaan teknik relaksasi pernapasan menurut Priharjo (2018) yaitu: (1) atur posisi agar rileks, tanpa beban pikiran. Posisi dapat duduk atau jika tidak mampu dapat berbaring di tempt tidur. (2) menarik atau menghirup na fas dalam dari hidung sehingga orngga paru-paru terisi oleh udara memalui hitungan 1, 2, 3, 4 kemudian ditahan sekitar 3 -5 detik. (3) menghebuskan nafas, hitung sampai tiga hitungan secara perlahan melalui mulut. (4) berkonsentrasi sgar rasa cemas/stress yang sedang dirasakan bisa berkurang dengan 
memejamkan mata. (5) mengulangi prosedur relaksasi perna fasan berulang sampai rasa cemas/stress berkurang. Minimal ulangi 10 kali dengan diselingi istirahat singkat setiap 5 kali.

\section{METODOLOGI}

Penelitian ini dilakukan dengan mengunakan pendekatan quasi experimental design, yaitu suatu penelitian yang memiliki bentuk menyerupai dengan eksperimen (Sugiyono, 2015). Quasy experimental biasanya digunakan ketika kontrol secara penuh tidak dimungkinkan seperti dalam penelitian eksperimental (Graziano \& Morgenstern, 1989). Rancangan penelitian yang digunakan adalah one group be/fore-after, (pretest-postest design) dimana akan dilihat perbedaan hasil test peserta sebelum dalon sesudah pelaksanaan variabel independent (Azwar, Saifuddin, M, 2005). Perlakuan treatment pada penelitian ini adalah metode relaksasi (R., 2016). Pada sampel penelitian ini sebelum diberikan treatment akan diukur terlebih dahulu tingkat stres. Setelah itu mereka akan melakukan metode relaksasi dan diakhir sesi akan diukur kembali tingkat stres (post test).

\section{HASIL DAN PEMBAHASAN}

Berdasarkan studi pendahuluan yang dilaksanakan, diketahui tingkat stress pada ibu saat mendampingi anak SFH (School From Home) di saat pandemic sekrang adalah tinggi. Tinggi rendahnya stress pada ibu diukur dengan instrument (Champlin, 2006)Depression Anxiety Stress Scales (DASS) yang dikembangkan oleh Lovibond,S.H dan Lovibond P.F pada tahun 1995 (Council, 2004). Kuesioner DASS terdiri dari 42 item yang mengukur general psychological distress seperti depresi, kecemasan dan stress. Kuesioner ini untuk mengukur tiga skala yaitu depresi, kecemasan dan stress yang masing-masing-masing skala memiliki 14 item pernyataan. Jawaban tes DASS ini terdiri atas 4 pilihan yang disuusn dalam bentk skala $0=$ tidak pernah, 1 = kadang-kadang, 2 = sering, 3 = sangat sering. Nilai yang diperoleh dari respon responden akan ditotal dan dikategorikan sesuai dengan tingkat gangguan psikologis responden. Respon tingkat kecemasan dikategorikan menjadi 5 yaitu nilai 0-7 = normal, 8-9= kecemasan ringan, 10-14 = kecemasan sedang, 15-19 kecemasan berat, $\geq 20$ kecemasan sangat berat. Respon stress dikategorikan menjadi 5 yaitu 0-14 = normal, 15-18 = stress ringan, 19-25 = stress sedang, $26-33=$ stress berat $\geq 34=$ stress sangat berat. Sedangkan respon depresi dibagi menjadi 5 kategori yaitu 0-9 = normal, 10-13 depresi ringan, 14-20 depresi sedang, 21-27 = depresi berat dan $\geq 28$ = depresi sangat berat. Selengkapnya lihat tabel 1 .

Tabel 1 bermakna bahwa terjadi penurunan yang cukup signifikan berdasarkan pada hasil perbedaan pretest dan posttest yang dilakukan. Disimpulkan bahwa terjadi penurunan stres yang dalam hal ini rata-rata penurunan yaitu 9,1 poin $(16,25 \%)$ diilustrasikan dengan grafik pada gambar 1 . Secara keseluruhan rata-rata skor pretes instrumen mengurangi tingkat stres dalam mendampingi anak school from home (SFH) memiliki rata-rata lebih tinggi/ parah $(28,3)$ dibandingkan dengan postes yaitu $(19,2)$.

Adapun hasil perbandingan skor antara pretes dan postes diatas dikuatkan dengan hasil uji wilcoxon (Purwanto, 2007) pada tabel 2. Berdasarkan hasil analisis data dengan Wilcoxon menunjukkan bahwa tujuan dari Metode Relaksasi untuk Mengurangi Tingkat Stres Pada Ibu dalam Mendampingi Anak SFH (School From Home) di Era Pandemi tercapai, yakni dengan adanya perubahan hasil pretes dan postes pada tingkat stres yang dimiliki ibu di Kabupaten Kuningan.

Kaidah yang digunakan adalah menguji hipotesis alternatif (Ha) yang berbunyi Metode Relaksasi dapat Mengurangi Tingkat Stres Pada Ibu dalam Mendampingi Anak SFH (School From Home) di Era Pandemi. Berdasarkan hasil pengujian wilcoxon, diperoleh perbedaan sebesar -2.201 pada nilai signifikansi hitung (sig.2taled) 0,028.

Metode relaksasi dengan tingkat stress pada ibu yang dirumuskan dalam penilitian ini adalah metode relaksasi guna mengurangi tingkat stress pada ibu yang mendampingi anak SFH. Asumsinya bahwa tingkat stress pada ibu perlu dikurangi karena akan berdampak pada 
keefektifitan pembelajaran anak di rumah. Relaksasi adalah reaksi-reaksi jasmaniah dalam keadaan tenang da emosional mediatif.

Tabel 1. Skor Pretest dan Posttest Ibu pada Penurunan Tingkat Stres dalam Mendampingi anak SFH

\begin{tabular}{|c|c|c|c|c|c|c|c|}
\hline No & Subjek & $\begin{array}{c}\text { Frekuensi } \\
\%\end{array}$ & Pretest & Kategori & Posttest & Kategori & Penurunan \\
\hline \multirow{2}{*}{1} & $A$ & $\mathrm{~F}$ & 25 & \multirow{2}{*}{$\mathrm{S}$} & 16 & \multirow{2}{*}{$\mathrm{R}$} & 9 \\
\hline & A & $\%$ & $44,64 \%$ & & $28,57 \%$ & & $16,07 \%$ \\
\hline \multirow{2}{*}{2} & & $\mathrm{~F}$ & 30 & \multirow{2}{*}{$\mathrm{P}$} & 19 & \multirow{2}{*}{ S } & 11 \\
\hline & B & $\%$ & $53,57 \%$ & & $33,93 \%$ & & $19,64 \%$ \\
\hline \multirow{2}{*}{3} & $C$ & $\mathrm{~F}$ & 33 & \multirow{2}{*}{$\mathrm{P}$} & 17 & \multirow{2}{*}{$\mathrm{R}$} & 16 \\
\hline & $C$ & $\%$ & $58,93 \%$ & & $30,36 \%$ & & $28,57 \%$ \\
\hline \multirow{2}{*}{4} & , & $\mathrm{F}$ & 27 & \multirow{2}{*}{$\mathrm{P}$} & 18 & \multirow[b]{2}{*}{ S } & 9 \\
\hline & $D$ & $\%$ & $48,21 \%$ & & $32,14 \%$ & & $16,07 \%$ \\
\hline \multirow{2}{*}{5} & $\mathrm{~F}$ & $\mathrm{~F}$ & 29 & \multirow{2}{*}{$\mathrm{P}$} & 25 & \multirow{2}{*}{$\mathrm{S}$} & 4 \\
\hline & $\mathrm{E}$ & $\%$ & $51,78 \%$ & & $44,64 \%$ & & $7,14 \%$ \\
\hline \multirow{2}{*}{6} & $\Gamma$ & $\mathrm{F}$ & 33 & \multirow[b]{2}{*}{$\mathrm{P}$} & 20 & \multirow[b]{2}{*}{ S } & 13 \\
\hline & $\mathrm{F}$ & $\%$ & $58,93 \%$ & & $35,71 \%$ & & $23,22 \%$ \\
\hline \multirow{2}{*}{7} & $G$ & $\mathrm{~F}$ & 26 & \multirow{2}{*}{$\mathrm{P}$} & 16 & \multirow{2}{*}{$\mathrm{R}$} & 10 \\
\hline & $G$ & $\%$ & $46,43 \%$ & & $28,57 \%$ & & $17,86 \%$ \\
\hline \multirow{2}{*}{8} & $H$ & $\mathrm{~F}$ & 29 & \multirow[b]{2}{*}{$\mathrm{P}$} & 24 & \multirow[b]{2}{*}{ S } & 5 \\
\hline & $\mathrm{H}$ & $\%$ & $51,78 \%$ & & $42,86 \%$ & & $8,92 \%$ \\
\hline \multirow{2}{*}{9} & I & $\mathrm{F}$ & 25 & \multirow{2}{*}{$\mathrm{S}$} & 19 & \multirow{2}{*}{ S } & 6 \\
\hline & & $\%$ & $44,64 \%$ & & $33,93 \%$ & & $10,71 \%$ \\
\hline \multirow{3}{*}{10} & I & $\mathrm{F}$ & 26 & \multirow[b]{2}{*}{$\mathrm{P}$} & 18 & \multirow[b]{2}{*}{$\mathrm{R}$} & 8 \\
\hline & $\mathrm{J}$ & $\%$ & $46,43 \%$ & & $32,14 \%$ & & $14,29 \%$ \\
\hline & \multicolumn{2}{|c|}{ Rata-rata } & 28,3 & $\mathbf{P}$ & 19,2 & $\mathbf{S}$ & 9,1 \\
\hline
\end{tabular}

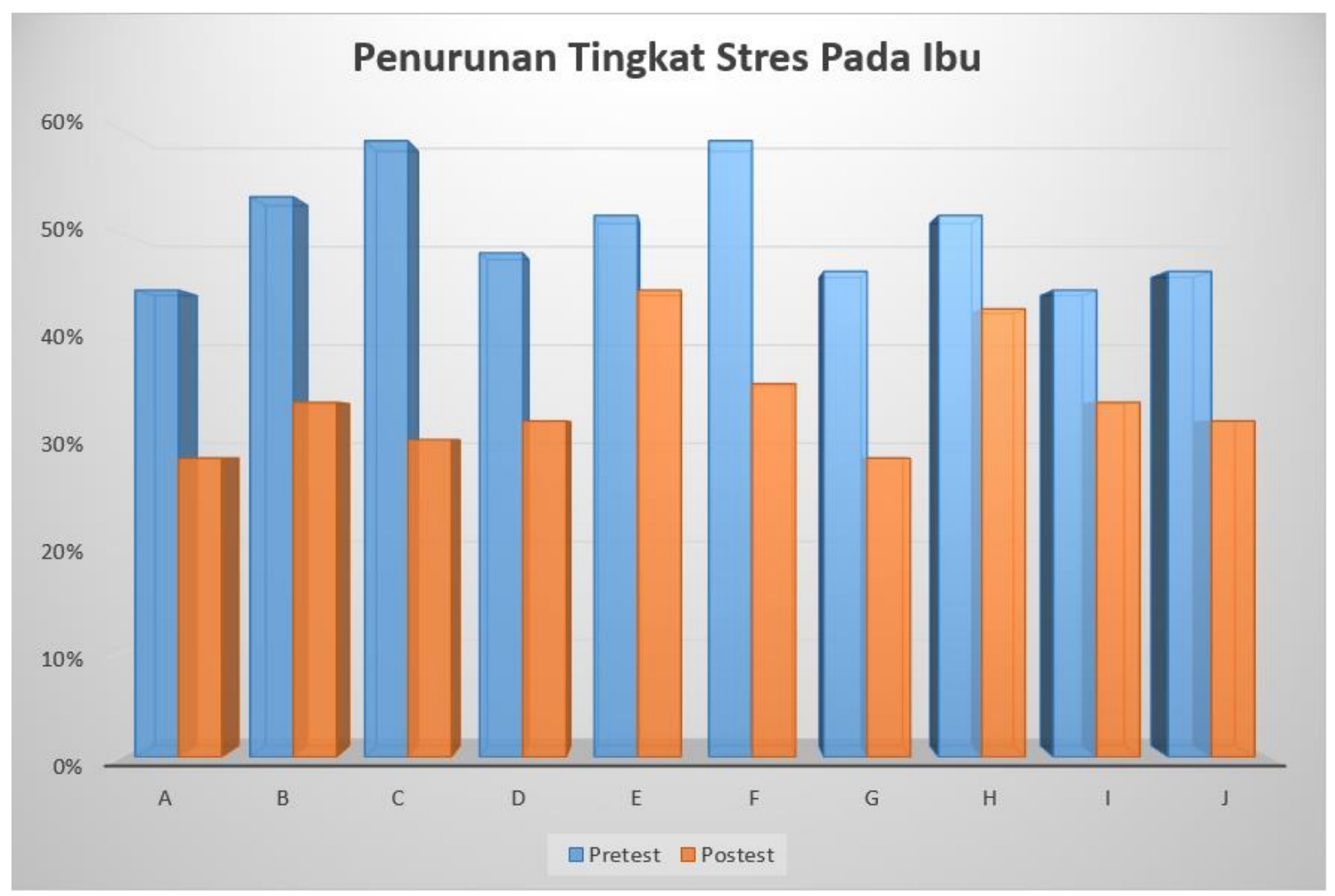

Gambar 1. Perbandingan Skor Pretes dan Postes Ibu pada Penurunan Tingkat Stres dalam Mendampingi anak SFH 
Tabel 2. Hasil Perhitungan Wilcoxon

\begin{tabular}{|c|c|c|c|}
\hline & $\mathrm{N}$ & Mean Rank & Sum of Ranks \\
\hline Evaluasi Akhir - Evaluasi Negative Ranks & $6^{a}$ & 3.50 & 21.00 \\
\hline Positive Ranks & $0^{\mathrm{b}}$ & .00 & .00 \\
\hline Ties & $0^{c}$ & & \\
\hline Total & 6 & & \\
\hline
\end{tabular}

a. Evaluasi Akhir < Evaluasi Awal

b. Evaluasi Akhir > Evaluasi Awal

c. Evaluasi Akhir $=$ Evaluasi Awal

Test Statistics ${ }^{b}$

\begin{tabular}{|c|c|}
\hline & $\begin{array}{c}\text { Evaluasi Akhir } \\
\text { - Evaluasi } \\
\text { Awal }\end{array}$ \\
\hline$Z$ & $-2.201^{\text {a }}$ \\
Asymp. Sig. (2-tailed) & .028 \\
\hline
\end{tabular}

a. Based on positive ranks.

b. Wilcoxon Signed Ranks Test

Teknik relaksasi merupakan salah satu teknik pengelolaan diri yang didasarkan pada cara kerja system saraf simpatis dan para simpatis. Selain itu juga, ketika otot-otot sudh dirilekskan maka akan menormalkan kembali fungsi-fungsi organ tubuh. Setelah seseorang melakukan relaksasi maka dapat membantu tubuhnya menjadi rileks. Selain itu juga, relaksasi merupakan proses merilekskan otot-otot yang mengalami ketegangan atau mengendorkan otot-otot dan pikiran agar tercapai kondisi yang nyaman atau berda pada gelombang otak alfa-beta (Yunus, 2014).

Jenis relaksasi menurut Miltenberger (2012) dibedakan menjadi empat macam yaitu relaksasi otot (progressive muscle), relaksasi pernapasan (diapbrogmatic breathing), relaksasi dengan cara mediasi (attention focusing exercises), dan relaksasi perilaku (behavioural relaxation training) dan lain sebagainya. Relaksasi yang dilakukan dalam penelitian ini adalah relaksasi pernapasan dalam, relaksasi otot progresif dan relaksasi pernapasan dalam dapat membantu individu menurunkan stress (WIGHT, 1970). Pernapasan yang tepat dapat menurunkan stress dan kebiasaan bernapas yang tepat penitng untuk kesehatan fisik dan mental (Davis, M, 1995).

Pelaksanaan teknik relaksasi pernapasan menurut Priharjo (2003) yaitu: (1) atur posisi agar rileks, tanpa beban pikiran. Posisi dapat duduk atau jika tidak mampu dapat berbaring di tempt tidur. (2) menarik atau menghirup nafas dalam dari hidung sehingga orngga paruparu terisi oleh udara memalui hitungan 1, 2, 3, 4 kemudian ditahan sekitar 3-5 detik. (3) menghebuskan nafas, hitung sampai tiga hitungan secara perlahan melalui mulut. (4) berkonsentrasi sgar rasa cemas/stress yang sedang dirasakan bisa berkurang dengan memejamkan mata. (5) mengulangi prosedur relaksasi pernafasan berulang sampai rasa cemas/stress berkurang. Minimal ulangi 10 kali dengan diselingi istirahat singkat setiap 5 kali.

Penelitian ini didukung penelitian sebelumnya, yaitu penelitian dari Fildzar yang berjudul “Kegiatan Relaksasi Sebagai Coping Stress di masa Pandemi Covid-19" memaparkan bahwa efektifitas metode relaksasi sebagai alternatif mengatasi stres selama pandemi Covid19. Sehingga relaksasi dapat dijadikan sebagai alternatif teknik sosial yang mendukung proses adaptasi individu dan kelompok, serta komunitas (Nasir, 2011). 


\section{SIMPULAN}

Metode relaksasi dapat menurunkan tingkat stress pada ibu ketika mendampingi anak SFH di era pandemi. Terbukti dari uji Wilcoxon yang dinyatakan dari nilai signifikan atau probabilitas $0,028<0,050$. Hal ini menandakan bahwa metode relaksasi efektif untuk mengurangi tingkat stress pada ibu, karena terjadi penurunan yang cukup signifikan berdasarkan pada hasil perbedaan pretest dan posttest yang dilakukan.

\section{UCAPAN TERIMA KASIH}

Terima kasih kami ucapkan kepada DRPM Kemendikbud Ristek yang telah memberikan hibah skema Penelitian Dosen Pemula (PDP) pendanaan tahun 2021 sehingga memudahkan penyusunan karya tulis ilmiah ini sebagai salah satu luaran penelitian. Segenap unsur pimpinan STKIP Muhammadiyah Kuningan, para pihak yang telah membantu penulisan karya tulis ilmiah ini dan juga reviewer serta editor jurnal, sehingga kami dapat mempublikasikan topik ini.

\section{DAFTAR PUSTAKA}

Abbasi, S. H. et al. (2018) 'Ethnic Differences in the Risk Factors and Severity of Coronary Artery Disease: a Patient-Based Study in Iran', Journal of Racial and Ethnic Health Disparities. Journal of Racial and Ethnic Health Disparities, 5(3), pp. 623-631. https:// doi.org/10.1007/s40615-017-0408-3

Arifa, F. N. (2020). Tantangan pelaksanaan kebijakan belajar dari rumah dalam masa darurat covid-19. Info Singkat: Kajian Singkat Terhadap Isu Aktual Dan Strategis, 7(1), 13-18.

Azwar, Saifuddin, M, A. (2005). Metode Penelitian. Pustaka Pelajar.

Chairini, N. (2013). Faktor-faktor yang berhubungan dengan stres pengasuhan pada ibu dengan anak usia prasekolah di posyandu kemiri muka. Skripsi, 1-93. http:/ / repository.uinjkt.ac.id

Champlin, J. P. (2006). Kamus Psikologi. Raja Grafindo Persada.

Council, N. S. (2004). Manajemen Stres. Manajemen Stres, 7.

Covid-, D. M. P. (2021). School From Home ( SFH ) : Perjuangan Para Orang Tua Siswa Usia Dini. Jurnal Sosial Humaniora Terapan, 3(2), 7-16.

Davis, M, E. (1995). Panduan Relaksasi dan Reduksi Stres (Terjemahan),. In Psikologi Islam (Issue 1). Penerbit Buku Kedokteran EGC.

Friedenberg, L. (1995). Psychological Testinf: Design, Analysis, and Use. Allyn \& Bacon A Simon \& Schuster Company.

GA, W. (1981). Experiental Learning and Change: Theory, Design and Practice. John Wiley \& Sons.

Graziano, A. M., \& Morgenstern, H. (1989). Research methods: a process of inquiry. Allyn \& Bacon.

Henry, J. and Crawford, J. (2005) The Short-Form Version of the Depression Anxiety Stress Scales (DASS-21): Construct Validity and Normative Data in a Large Non-Clinical Sample. British Journal of Clinical Psychology, 44, 227-239. https:// doi.org/10.1348/014466505X29657

Huang, Y., \& Zhao, N. (2020). Generalized anxiety disorder, depressive symptoms and sleep quality during COVID-19 outbreak in China: a web-based cross-sectional survey. Psychiatry Research, 288, 288. https://doi.org/10.1016/j.psychres.2020.112954

Kirkpatrick, Donald, L. (2006). Evaluating Training Program 2nd Edition. Berrete-Koehler Publisher.

McPheat. (2010). Emotional intelligence: MDT Training (1st Ed. Lo).

Miltenberger, R. (2012). Behavior Modification (Principles and Procedures). Wadsworth Cengange Learning.

Nasir, A. \& A. M. (2011). Dasar-dasar Keperwatan jiwa. Salemba Medika. 
Priharjo. (2003). Perawatan Nyeri. EGC.

Priharjo. (2018). Prosedur Teknik Relaksasi Nafas Dalam. Diakses Tanggal 20 November 2018. http:// prosedurteknikrelaksasinafasdalam.go.id

Purwanto, E. (2007). Metode Penelitian Kuantitatif. Fakultas Ilmu Pendidikan Universitas Negeri Semarang.

R., L. (2016). Pengaruh Stres pada Kesehatan Jaringan Periodontal. Jurnal Skala Husada, 13(1), 81-89.

Sarafino, E.P., \& Smith, T. W. (2011). Health Psychology: Biopsychosocial Interactions (7th ed.). John Wiley \& Sons. Inc.

Sari, A. D. K., \& Subandi. (2015). Pelatihan Teknik Relaksasi untuk Menurunkan Kecemasan pada Primary Caregiver Penderita Kanker Payudara. Gadjah Mada Journal of Professional Psychology, 1(3), 173-192.

Sugiyono. (2015). Statistik Nonparametris Untuk Penelitian. Book, 1-370.

T.V, S. (2017). Pengaruh Program Zumba Terhadap Penurunan Stres Mahasiswa. UPI.

Wight, A. R. (1970). Participative Education And the Inevitable Revolution. The Journal of Creative Behavior, 4(4), 234-282. https://doi.org/10.1002/j.2162-6057.1970.tb00864.x

Yunus, A.(2014). Desain Sistem Pembelajaran Dalam Konteks Kurikulum 2013. Bandung: Refika Aditama. 